\title{
Very Short Intramolecular Hydrogen Bonds in the Crystal Structure of 1-[Bis(4-Fluorophenyl)Methyl]Piperazinediium Dimaleate
}

\author{
A. S. Dayananda $\cdot$ Grzegorz Dutkiewicz $\cdot$ \\ H. S. Yathirajan $\cdot$ B. Narayana $\cdot$ Maciej Kubicki
}

Received: 11 March 2012/ Accepted: 4 August 2012/Published online: 23 August 2012

(C) The Author(s) 2012. This article is published with open access at Springerlink.com

\begin{abstract}
The crystal structure of 1-[bis(4-fluorophenyl)methyl]piperazine-1,4-diium dimaleate has been determined at 130(1) $\mathrm{K}$ in order to analyze the short intramolecular hydrogen bonds in maleate anions. The salt crystallizes in the orthorhombic Pbca space group with unitcell parameters: $\mathrm{a}=9.7143(3) \AA, \quad \mathrm{b}=18.2668(3) \AA$, $\mathrm{c}=27.2219(8) \AA$. The two anions display different kinds of very short intramolecular hydrogen bonds $(\mathrm{O} \cdots \mathrm{O}$ distance is 2.4184(12) and 2.4414(13) $⿱$ ). In one of the anions the hydrogen atom is located asymmetrically, much closer to one of the oxygen atoms than to the other, while in the other anion the hydrogen atom is almost in the middle between two oxygen atoms. These positions were confirmed by the analysis of the difference Fourier maps. The dication is protonated on both nitrogen atoms of piperazine ring (which is in quite regular chair conformation), and all three $\mathrm{N}-\mathrm{H}$ groups of the cation are involved in short and linear hydrogen bonds with oxygen atoms of the anions, not involved in intramolecular hydrogen bonds. These hydrogen bonds connect cations and anions into ribbons expanding along $b$-axis. Much weaker $\mathrm{C}-\mathrm{H} \cdots \mathrm{F}, \mathrm{C}-\mathrm{H} \cdots \mathrm{O}$ and $\mathrm{C}-\mathrm{H} \cdots \pi$ interactions take part, along with the electrostatic and van der Waals interactions, in the determination of the crystal packing.
\end{abstract}

A. S. Dayananda $\cdot$ H. S. Yathirajan

Department of Studies in Chemistry, University of Mysore,

Manasagangotri, Mysore 570 006, India

G. Dutkiewicz · M. Kubicki ( $\square)$

Faculty of Chemistry, Adam Mickiewicz University,

Grunwaldzka 6, 60-780 Poznań, Poland

e-mail: mkubicki@amu.edu.pl

B. Narayana

Department of Studies in Chemistry, Mangalore University,

Mangalagangotri, Mangalore 574 199, India
Keywords Flunarizine derivatives - Maleate, short hydrogen bonds · Conformation · Crystal packing

\section{Results and Discussion}

1-[bis(4-fluorophenyl)methyl]piperazine (1) is an intermediate for the preparation of flunarizine, 1-[bis(4-fluorophenyl)methyl]-4-[(2E)-3-phenylprop-2-en-1-yl]piperazine, which is a calcium channel blocker $[1,2]$ and has been used for treatment of migraine and seems to be a little less effective than propranolol [3].

The crystal structures of some mono-salts of $\mathbf{1}$ (always protonated at N34 nitrogen atom) have been reported: 2-(2phenylethyl)benzoate [4] and picrate [5], as well as the structures of the unsubstituted free base, 1-benzhydrylpiperazine [6] and some of its derivatives' di-salts, e.g. 1-benzhydryl-4-(2-benzoyl-ethyl)piperazinium tetrachlorocuprate(ii) hydrate [7] or 1-diphenylmethyl-4-ethylpiperazine-1,4-diium dichloride [8]. Here we present the first crystal structure that contains the dication of $\mathbf{1}$, namely 1-[bis(4-fluorophenyl)methyl]piperazine-1,4-diium dimaleate (1dim, Scheme 1). No phase transition has been observed between room temperature and $100 \mathrm{~K}$.

\section{Molecular Structure}

The asymmetric part of the unit cell of 1dim contains one dication and two maleate anions (Fig. 1). The cation is protonated at both nitrogen atoms of piperazine ring, the positions of appropriate hydrogen atoms were found in the difference Fourier maps and successfully refined without constraints. The piperazinium ring is in the chair conformation, and the small values of asymmetry parameters 
<smiles>[X][C@H](c1ccc(F)cc1)[NH+]1CC[NH2+]CC1</smiles>

Scheme 1 Molecular formula of the salt 1dim

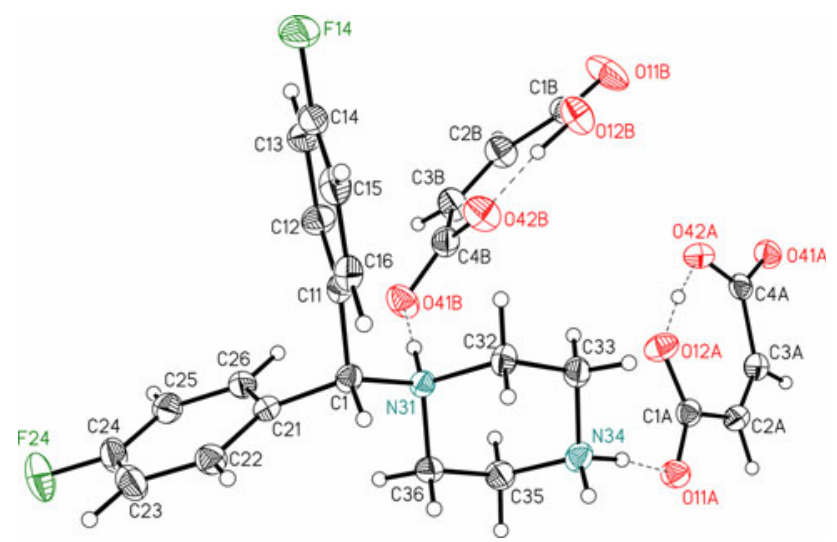

Fig. 1 Anisotropic ellipsoid representation of the molecular complex of 1dim_100, together with atom labeling scheme [14]. The ellipsoids are drawn at $50 \%$ probability level, hydrogen atoms are depicted as spheres with arbitrary radii, hydrogen bonds are shown as dashed lines

(which measure the deviations from the ideal symmetry of a given conformation [9]) show that the distortions are relatively unimportant. Table 1 lists some relevant geometrical parameters. The hydrogen atom at N31 is in an axial position $(\mathrm{C} 33-\mathrm{C} 32-\mathrm{N} 31-\mathrm{H} 31$ torsion angle is $-62.6(11)^{\circ}$ and $\mathrm{C} 35-\mathrm{C} 36-\mathrm{N} 31-\mathrm{H} 31$ 61.4(11) ${ }^{\circ}$.

In both maleate anions strong intramolecular hydrogen

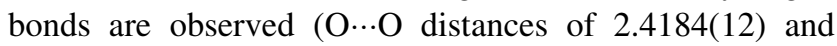
$2.4414(13) \AA$ ). Such bonds, enforced by cis conformation of the double bond $\left(\mathrm{C}-\mathrm{C}=\mathrm{C}-\mathrm{C}\right.$ torsion angles are $1.0(2)^{\circ}$ and $0.7(2)^{\circ}$ in anions $\mathrm{A}$ and $\mathrm{B}$ respectively) were also observed in other maleates. For instance, the imidazolium hydrogen maleate and calcium di(hydrogen maleate) were studied by the difference X-N (X-ray vs. neutron) method [10]. Figure 2 shows the distribution of the $\mathrm{O} \cdots \mathrm{O}$ distances and $\mathrm{O}-\mathrm{H} \cdots \mathrm{O}$ angles for 169 hits found in the Cambridge Structural Database [11]; ver.5.33 of Nov. 2011, updated Feb. 2012; search criteria: organic, $\mathrm{R}<0.075$, absolute
Table 1 Selected geometrical parameters $\left(\AA{ }^{\circ}\right)$ with s.u.'s in parentheses

\begin{tabular}{|c|c|}
\hline $\mathrm{C} 1-\mathrm{C} 11$ & $1.5179(15)$ \\
\hline $\mathrm{C} 1-\mathrm{C} 21$ & $1.5151(15)$ \\
\hline $\mathrm{C} 1-\mathrm{N} 31$ & $1.5219(13)$ \\
\hline $\mathrm{N} 31-\mathrm{C} 32$ & $1.5004(14)$ \\
\hline $\mathrm{N} 31-\mathrm{C} 36$ & $1.4999(14)$ \\
\hline N34-C33 & $1.4887(15)$ \\
\hline N34-C35 & $1.4892(15)$ \\
\hline $\mathrm{C} 1 \mathrm{~A}-\mathrm{O} 11 \mathrm{~A}$ & $1.2400(14)$ \\
\hline $\mathrm{C} 1 \mathrm{~A}-\mathrm{O} 12 \mathrm{~A}$ & $1.2836(14)$ \\
\hline $\mathrm{C} 1 \mathrm{~A}-\mathrm{C} 2 \mathrm{~A}$ & $1.4984(16)$ \\
\hline $\mathrm{C} 2 \mathrm{~A}-\mathrm{C} 3 \mathrm{~A}$ & $1.3364(17)$ \\
\hline $\mathrm{C} 3 \mathrm{~A}-\mathrm{C} 4 \mathrm{~A}$ & $1.5004(16)$ \\
\hline $\mathrm{C} 4 \mathrm{~A}-\mathrm{O} 41 \mathrm{~A}$ & $1.2330(14)$ \\
\hline $\mathrm{C} 4 \mathrm{~A}-\mathrm{O} 42 \mathrm{~A}$ & $1.2922(15)$ \\
\hline C1B-O11B & $1.2181(16)$ \\
\hline $\mathrm{C} 1 \mathrm{~B}-\mathrm{O} 12 \mathrm{~B}$ & $1.2990(17)$ \\
\hline $\mathrm{C} 1 \mathrm{~B}-\mathrm{C} 2 \mathrm{~B}$ & $1.4958(18)$ \\
\hline $\mathrm{C} 2 \mathrm{~B}-\mathrm{C} 3 \mathrm{~B}$ & $1.3357(17)$ \\
\hline $\mathrm{C} 3 \mathrm{~B}-\mathrm{C} 4 \mathrm{~B}$ & $1.4969(16)$ \\
\hline C4B-O41B & $1.2615(16)$ \\
\hline $\mathrm{C} 4 \mathrm{~B}-\mathrm{O} 42 \mathrm{~B}$ & $1.2523(15)$ \\
\hline $\mathrm{C} 1 \mathrm{~A}-\mathrm{C} 2 \mathrm{~A}-\mathrm{C} 3 \mathrm{~A}$ & $130.70(11)$ \\
\hline $\mathrm{C} 2 \mathrm{~A}-\mathrm{C} 3 \mathrm{~A}-\mathrm{C} 4 \mathrm{~A}$ & $130.33(11)$ \\
\hline $\mathrm{C} 1 \mathrm{~B}-\mathrm{C} 2 \mathrm{~B}-\mathrm{C} 3 \mathrm{~B}$ & 131.01(12) \\
\hline $\mathrm{C} 2 \mathrm{~B}-\mathrm{C} 3 \mathrm{~B}-\mathrm{C} 4 \mathrm{~B}$ & $129.06(12)$ \\
\hline N31-C32-C33-N34 & $-54.42(13)$ \\
\hline C32-C33-N34-C35 & $55.77(12)$ \\
\hline C33-N34-C35-C36 & $-58.53(12)$ \\
\hline N34-C35-C36-N31 & $59.72(12)$ \\
\hline C35-C36-N31-C32 & $-56.38(12)$ \\
\hline C36-N31-C32-C33 & $53.88(12)$ \\
\hline C35-C36-N31-C1 & $-176.85(9)$ \\
\hline C33-C32-N31-C1 & $174.70(9)$ \\
\hline $\mathrm{C} 1 \mathrm{~A}-\mathrm{C} 2 \mathrm{~A}-\mathrm{C} 3 \mathrm{~A}-\mathrm{C} 4 \mathrm{~A}$ & $1.0(2)$ \\
\hline $\mathrm{O} 11 \mathrm{~A}-\mathrm{C} 1 \mathrm{~A}-\mathrm{C} 2 \mathrm{~A}-\mathrm{C} 3 \mathrm{~A}$ & $178.01(12)$ \\
\hline $\mathrm{O} 12 \mathrm{~A}-\mathrm{C} 1 \mathrm{~A}-\mathrm{C} 2 \mathrm{~A}-\mathrm{C} 3 \mathrm{~A}$ & $-1.08(19)$ \\
\hline $\mathrm{C} 2 \mathrm{~A}-\mathrm{C} 3 \mathrm{~A}-\mathrm{C} 4 \mathrm{~A}-\mathrm{O} 41 \mathrm{~A}$ & $176.96(12)$ \\
\hline $\mathrm{C} 2 \mathrm{~A}-\mathrm{C} 3 \mathrm{~A}-\mathrm{C} 4 \mathrm{~A}-\mathrm{O} 42 \mathrm{~A}$ & $-2.87(19)$ \\
\hline $\mathrm{C} 1 \mathrm{~B}-\mathrm{C} 2 \mathrm{~B}-\mathrm{C} 3 \mathrm{~B}-\mathrm{C} 4 \mathrm{~B}$ & $0.7(2)$ \\
\hline $\mathrm{O} 11 \mathrm{~B}-\mathrm{C} 1 \mathrm{~B}-\mathrm{C} 2 \mathrm{~B}-\mathrm{C} 3 \mathrm{~B}$ & $169.89(15)$ \\
\hline $\mathrm{O} 12 \mathrm{~B}-\mathrm{C} 1 \mathrm{~B}-\mathrm{C} 2 \mathrm{~B}-\mathrm{C} 3 \mathrm{~B}$ & $-9.4(2)$ \\
\hline $\mathrm{C} 2 \mathrm{~B}-\mathrm{C} 3 \mathrm{~B}-\mathrm{C} 4 \mathrm{~B}-\mathrm{O} 41 \mathrm{~B}$ & $12.0(2)$ \\
\hline $\mathrm{C} 2 \mathrm{~B}-\mathrm{C} 3 \mathrm{~B}-\mathrm{C} 4 \mathrm{~B}-\mathrm{O} 42 \mathrm{~B}$ & $-167.72(14)$ \\
\hline
\end{tabular}

value of the $\mathrm{C}-\mathrm{C}-\mathrm{C}-\mathrm{C}$ torsion angle less than $30^{\circ}, \mathrm{O} \cdots \mathrm{O}$ contact less than $3 \AA$ ).

In the structure of 1dim the details of intramolecular hydrogen bonds in two symmetry-independent molecules are different, as far as the standard X-ray diffraction can 

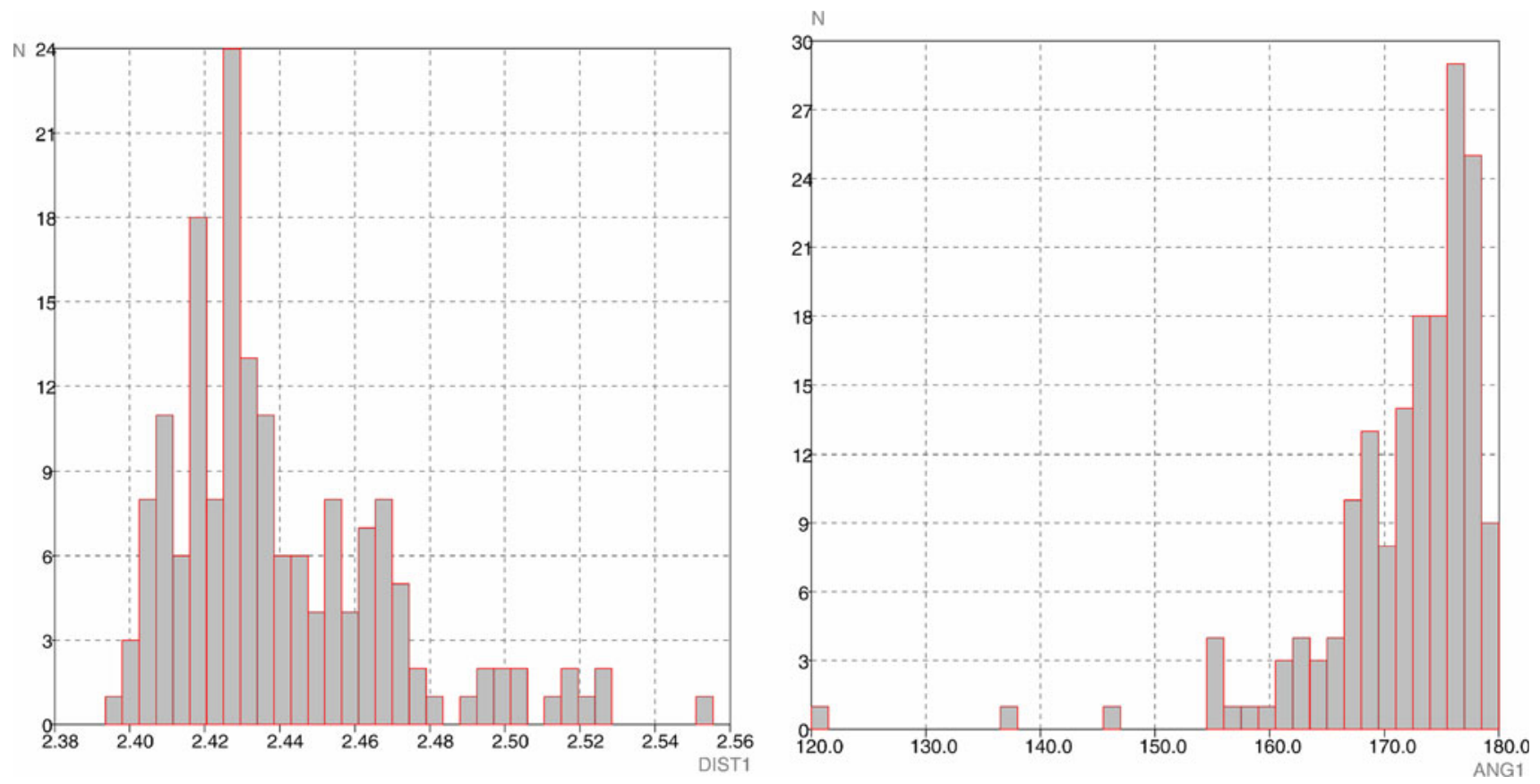

Fig. 2 The distribution of $\mathrm{O} \cdots \mathrm{O}$ distances (left) and $\mathrm{O}-\mathrm{H} \cdots \mathrm{O}$ angles (right) in maleate anions found in the Cambridge Structural Database

determine this. The hydrogen bond in the anion $\mathrm{A}$ is almost symmetrical $(\mathrm{O}-\mathrm{H}$ and $\mathrm{H} \cdots \mathrm{O}$ distances are 1.15(2) and $1.27(2) \AA$ while in the anion B it is better localized near one of the $\mathrm{O}$ atoms (appropriate distances are 0.99(2) and $1.45(2) \AA$ ). The reasonability of these results is somehow confirmed by the difference electron density plots, calculated after removing the hydrogen atom (Fig. 3a, b), where the results for additional data collection at room temperature (CCDC-870693) are also shown for comparison.

Interestingly, these differences seem to be correlated with the geometrical features of both anions. Anion A (with more "symmetrical" hydrogen bond) is almost ideally planar, maximum deviation from the mean plane calculated for all non-hydrogen atoms is only 0.0373(8) $\AA$ and the $\mathrm{COO}$ groups make the dihedral angles of $2.43(18)^{\circ}$ and $1.44(20)^{\circ}$ with perfectly planar (within 00035(8) $\AA$ ) $\mathrm{C}-\mathrm{C}=\mathrm{C}-\mathrm{C}$ fragment. In contrast, anion $\mathrm{B}$ is significantly twisted: the dihedral angles between $\mathrm{COO}$ groups and planar $(0.0024(9) \AA)$ carbon skeleton are as large as $9.4(2)^{\circ}$ and $12.54(15)^{\circ}$.

\section{Crystal Packing}

In the crystal, the "building block" consists of a dication and two anions connected by the strong, linear hydrogen bonds (cf. Fig. 1; Table 2) that involve two $\mathrm{N}-\mathrm{H}$ groups of cation (different nitrogen atoms) and two oxygen atoms from two anions, not involved in intramolecular hydrogen bonding. These blocks are connected by means of another
$\mathrm{N}-\mathrm{H} \cdots \mathrm{O}$ hydrogen bond and quite strong $\mathrm{C}-\mathrm{H} \cdots \mathrm{O}$ bond into the infinite chains along y direction (Fig. 4; Table 2).

This figure shows that the anion A connects two cations by means of $\mathrm{N}-\mathrm{H} \cdots \mathrm{O}$ hydrogen bonds, while anion $\mathrm{B}$ by one $\mathrm{N}-\mathrm{H} \cdots \mathrm{O}$ and one $\mathrm{C}-\mathrm{H} \cdots \mathrm{O}$ interactions. These chains are then connected by weaker contacts $(\mathrm{C}-\mathrm{H} \cdots \mathrm{O}, \mathrm{C}-\mathrm{H} \cdots \pi$ and $\mathrm{C}-\mathrm{H} \cdots \mathrm{F}$ ) into three-dimensional crystal structure (Fig. 5; Table 2).

\section{Experimental}

4,4'-Difluorobenzhydryl piperazine $(2.88 \mathrm{~g}, 0.01 \mathrm{~mol})$ in $10 \mathrm{ml}$ of benzene was mixed with maleic acid $(1.16 \mathrm{~g}$, $0.01 \mathrm{~mol}$ ) in $10 \mathrm{ml}$ of toluene. Both the solutions were mixed and stirred in a beaker at $333 \mathrm{~K}$ for $30 \mathrm{~min}$. The mixture was kept aside for a day at room temperature. The formed salt was filtered and dried in a vacuum desiccator over phosphorous pentoxide. The compound was recrystallized from a mixture of (1:1) ethanol and acetonitrile by slow evaporation (m.p.: 395-398 K).

$\mathrm{X}$-ray diffraction data were collected at $130(1) \mathrm{K}$ by the $\omega$-scan technique, on an Agilent Technologies four-circle SuperNova diffractometer equipped with Atlas detector [12] equipped with Nova microfocus $\mathrm{Cu} \mathrm{K}_{\alpha}$ radiation source $(\lambda=1.54178 \AA)$. The temperature was controlled with an Oxford Instruments Cryosystem device. The data were corrected for Lorentz-polarization effects as well as for absorption (multiscan) [12]. Accurate unit-cell parameters were determined by a least-squares fit of and 9393 

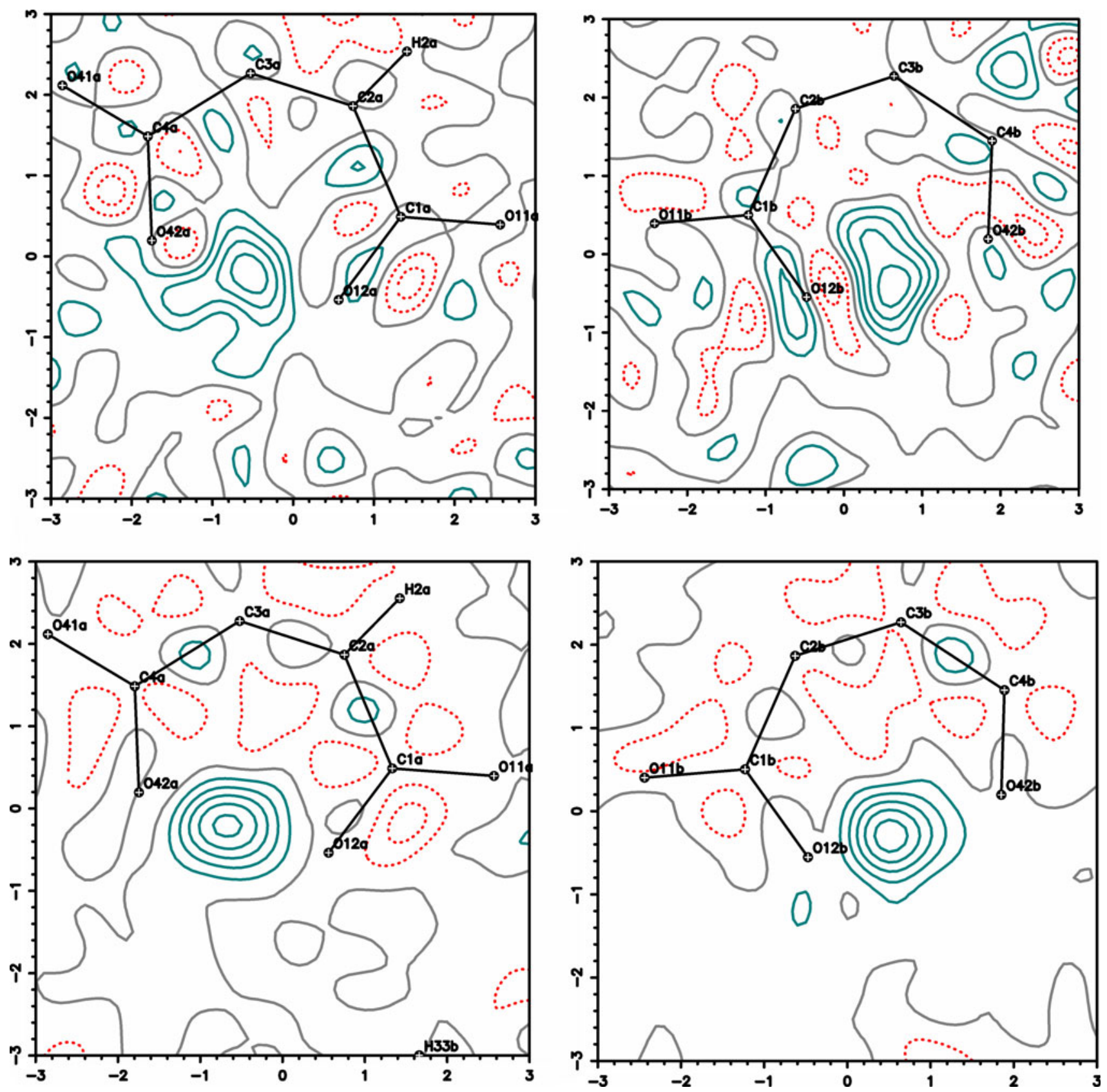

Fig. 3 The plot of the residual electron density across the $\mathrm{O} \cdots \mathrm{O}$ direction of the anions A (left) and B (right) at room temperature (top) and at $100 \mathrm{~K}$ (bottom). The hydrogen atoms were removed, the

contours are drawn every $0.1 \mathrm{e} \AA^{-3}$ Maximum and minimum values of the electron density are 0.53 and $-0.19 \mathrm{e} \AA^{-3}$

reflections of highest intensity, chosen from the whole experiment. The calculations were mainly performed within the WinGX program system [13]. The structures were solved with SIR92 [14] and refined with the fullmatrix least-squares procedure on $\mathrm{F}^{2}$ by SHELXL97 [15]. Scattering factors incorporated in SHELXL97 were used. The function $\Sigma \mathrm{w}\left(\left|\mathrm{F}_{\mathrm{o}}\right|^{2}-\left|\mathrm{F}_{\mathrm{o}}\right|^{2}\right)^{2}$ was minimized, with $\mathrm{w}^{-1}=\left[\sigma^{2}\left(\mathrm{~F}_{\mathrm{o}}\right)^{2}+(0.0411 \cdot \mathrm{P})^{2}+1.544 \cdot \mathrm{P}\right]$, where $\mathrm{P}=[\mathrm{Max}$ $\left(\mathrm{F}_{\mathrm{o}}^{2}, 0\right)+2 \mathrm{~F}_{\mathrm{c}}^{2} \mathrm{c} / 3$. All non-hydrogen atoms were refined

anisotropically; all hydrogen atoms were found in difference Fourier maps and isotropically refined. Relevant crystal data are listed in Table 3, together with refinement details.

Crystallographic data (excluding structure factors) for the structural analysis has been deposited with the Cambridge Crystallographic Data Centre, No. 870694. Additionally, data for room temperature structure have been also deposited as CCDC 870693. Copies of this 
Table 2 Short contact data $\left(\AA,{ }^{\circ}\right)$; CgA denotes the middlepoint of the ring $\mathrm{C} 11 \cdots \mathrm{C} 16$, and $\mathrm{CgB}-$ of the ring $\mathrm{C} 21 \cdots \mathrm{C} 26$
Symmetry codes: ${ }^{\mathrm{i}} 1 / 2-\mathrm{x}$,

$1 / 2+\mathrm{y}, \mathrm{z} ;{ }^{\mathrm{ii}} 1 / 2+\mathrm{x}, 1 / 2-\mathrm{y}$,

$1-\mathrm{z} ;{ }^{\mathrm{iii}} 3 / 2-\mathrm{x}, 1 / 2+\mathrm{y}$,

$\mathrm{z} ;{ }^{\mathrm{iv}}-1 / 2+\mathrm{x}, \mathrm{y}, 1 / 2-\mathrm{z}$;

v $1 / 2-x,-1 / 2+y, z$

Fig. 4 A ribbon of the cations and anions as seen approximately along $x$ direction ( $y$ across, $z$ down) [14]; hydrogen bonds are shown as dashed lines

\begin{tabular}{|c|c|c|c|c|c|c|}
\hline $\mathrm{D}$ & $\mathrm{H}$ & A & D-H & $\mathrm{H} \cdots \mathrm{A}$ & $\mathrm{D} \cdots \mathrm{A}$ & $\mathrm{D}-\mathrm{H} \cdots \mathrm{A}$ \\
\hline O12A & H42A & O42A & $1.27(2)$ & $1.15(2)$ & $2.4184(12)$ & $174(2)$ \\
\hline O12B & H12B & O42B & $0.99(2)$ & $1.45(2)$ & $2.4414(13)$ & $173(2)$ \\
\hline N31 & H31 & O41B & $0.981(18)$ & $1.719(18)$ & $2.6921(12)$ & $170.7(16)$ \\
\hline N34 & H34A & O11A & $0.980(18)$ & $1.799(18)$ & $2.7553(13)$ & $164.5(15)$ \\
\hline N34 & H34B & $\mathrm{O} 41 \mathrm{~A}^{\mathrm{i}}$ & $0.921(19)$ & $1.943(19)$ & $2.8208(13)$ & $158.7(16)$ \\
\hline $\mathrm{C} 1$ & $\mathrm{H} 1$ & O11A $\mathrm{A}^{\mathrm{ii}}$ & $0.972(14)$ & $2.383(14)$ & $3.3224(13)$ & $162.6(11)$ \\
\hline $\mathrm{C} 23$ & $\mathrm{H} 23$ & $\mathrm{~F} 14^{\mathrm{iii}}$ & $0.963(18)$ & $2.521(17)$ & $3.2810(15)$ & $135.8(14)$ \\
\hline C33 & H33B & O42B & $0.987(15)$ & $2.526(14)$ & $3.1869(15)$ & $124.2(10)$ \\
\hline C36 & H36B & $\mathrm{O} 42 \mathrm{~B}^{\mathrm{i}}$ & $0.969(16)$ & $2.396(15)$ & $3.0621(15)$ & $125.5(12)$ \\
\hline $\mathrm{C} 25$ & $\mathrm{H} 25$ & $\mathrm{CgA}^{\mathrm{iv}}$ & $0.944(18)$ & $2.931(17)$ & $3.5538(16)$ & $124.7(12)$ \\
\hline $\mathrm{C} 2 \mathrm{~B}$ & $\mathrm{H} 2 \mathrm{~B}$ & $\mathrm{CgB}^{\mathrm{v}}$ & $0.973(17)$ & $2.747(17)$ & $3.6734(17)$ & $159.4(12)$ \\
\hline
\end{tabular}

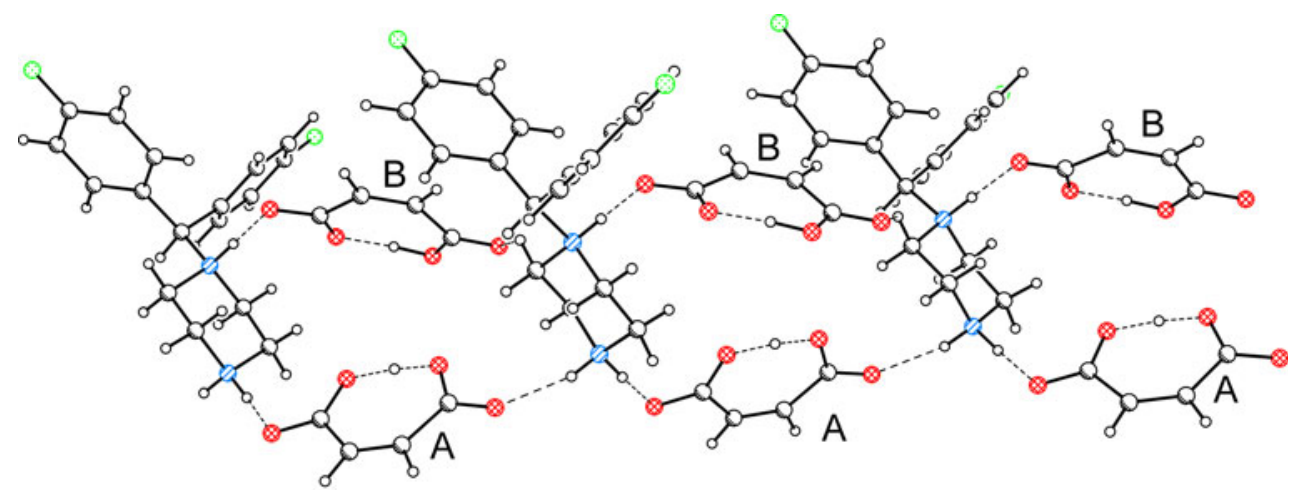

(iii) (i)
Fig. 5 Crystal packing of 1dim as seen along $x$-direction; hydrogen bonds and weak interactions (see text) are shown as dashed lines [14]

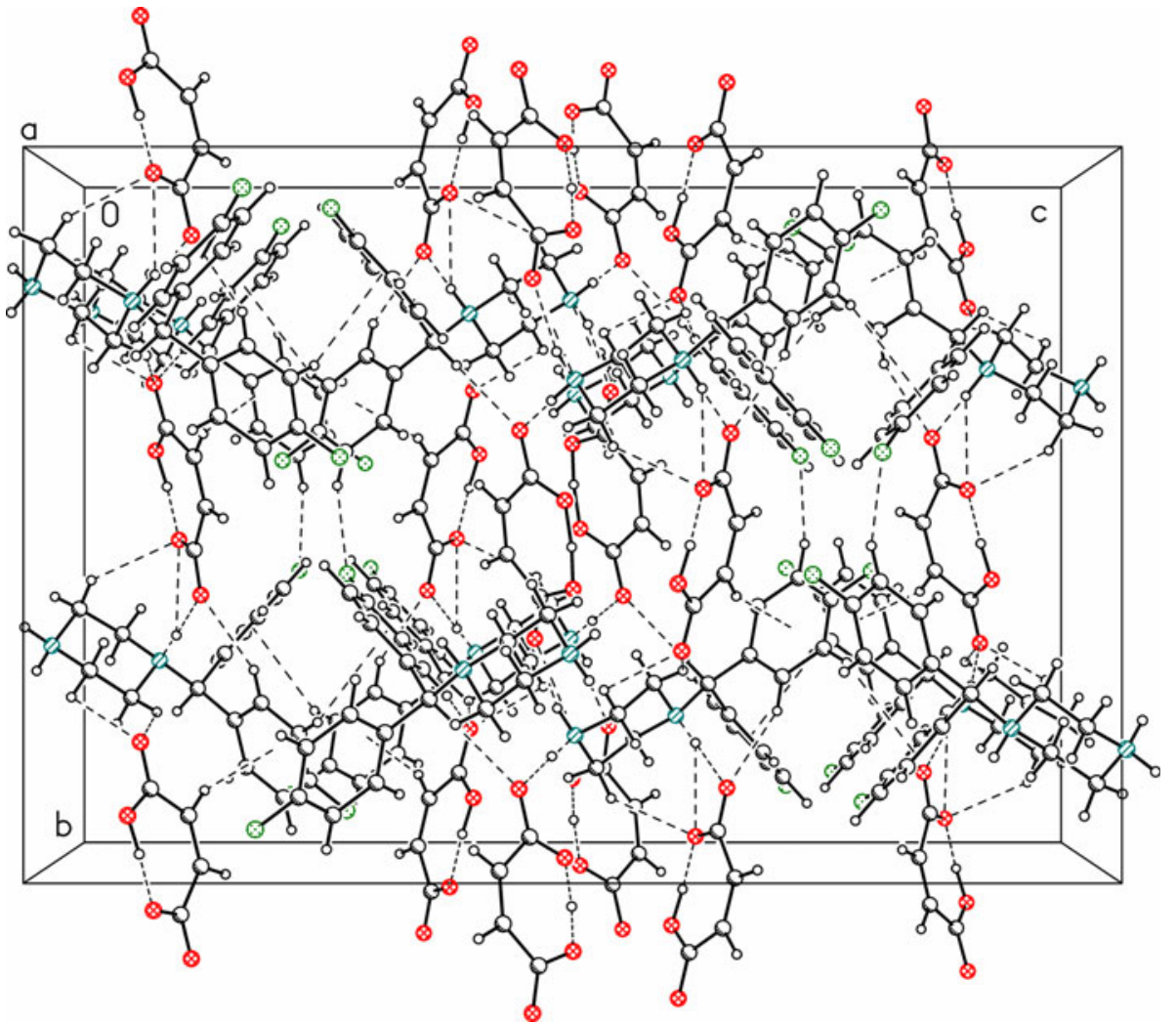


Table 3 Crystallographic data and refinement details

\begin{tabular}{|c|c|}
\hline Formula & $\mathrm{C}_{17} \mathrm{H}_{20} \mathrm{~F}_{2} \mathrm{~N}_{2}{ }^{2+} \cdot 2\left(\mathrm{C}_{4} \mathrm{H}_{3} \mathrm{O}_{4}\right)^{-}$ \\
\hline Formula weight & 520.48 \\
\hline Crystal system & Orthorhombic \\
\hline Space group & Pbca \\
\hline $\mathrm{a}(\AA)$ & $9.7143(3)$ \\
\hline $\mathrm{b}(\AA)$ & $18.2668(3)$ \\
\hline$c(\AA)$ & $27.2219(8)$ \\
\hline $\mathrm{V}\left(\AA^{3}\right)$ & $4830.5(2)$ \\
\hline $\mathrm{Z}$ & 8 \\
\hline$D_{x}\left(g \mathrm{~cm}^{-3}\right)$ & 1.43 \\
\hline $\mathrm{F}(000)$ & 2176 \\
\hline$\mu\left(\mathrm{mm}^{-1}\right)$ & 1.00 \\
\hline Crystal size (mm) & $0.3 \times 0.2 \times 0.15$ \\
\hline$\Theta$ range $\left(^{\circ}\right)$ & $3.25-73.75$ \\
\hline hkl range & $\begin{array}{l}-11 \leq \mathrm{h} \leq 4 \\
-22 \leq \mathrm{k} \leq 22 \\
-33 \leq 1 \leq 32\end{array}$ \\
\hline \multicolumn{2}{|l|}{ Reflections } \\
\hline Collected & 12162 \\
\hline Unique $\left(\mathrm{R}_{\text {int }}\right)$ & $4749(0.014)$ \\
\hline With $\mathrm{I}>2 \sigma(\mathrm{I})$ & 4548 \\
\hline Number of parameters & 438 \\
\hline $\mathrm{R}(\mathrm{F})[\mathrm{I}>2 \sigma(\mathrm{I})]$ & 0.033 \\
\hline $\mathrm{wR}\left(\mathrm{F}^{2}\right)[\mathrm{I}>2 \sigma(\mathrm{I})]$ & 0.083 \\
\hline $\mathrm{R}(\mathrm{F})$ [all data] & 0.034 \\
\hline$w R\left(F^{2}\right)$ [all data] & 0.083 \\
\hline Goodness of fit & 1.08 \\
\hline $\max / \min \Delta \rho\left(\mathrm{e} \AA^{-3}\right)$ & $0.26 /-0.23$ \\
\hline
\end{tabular}

Acknowledgments ASD thanks the University of Mysore for research facilities. HSY thanks R. L. Fine Chem., Bengaluru, for the gift sample of the title compound.

Open Access This article is distributed under the terms of the Creative Commons Attribution License which permits any use, distribution, and reproduction in any medium, provided the original author(s) and the source are credited.

\section{References}

1. Ell J, Gresty M (1983) J Neurol Neurosurg Psych 45:716

2. Lee JA, Watson LA, Boothby G (1986) Aviat Space Environ Med $57: 45$

3. Verspeelt J, De Locht P, Amery WK (1996) Eur J Clin Pharmacol 51:15

4. Betz R, Gerber T, Hosten E, Dayananda AS, Yathirajan HS (2011) Acta Cryst E67:02783

5. Betz R, Gerber T, Hosten E, Dayananda AS, Yathirajan HS, Narayana B (2011) Acta Cryst E67:02587

6. Naveen S, Swamy SN, Basappa, Swamy BP, Anandalwar SM, Prasad JS, Rangappa KS (2006) Anal Sci 22:x41

7. Macíček J, Tcholakova J, Parvanova M (1993) Acta Cryst C49:788

8. Qiao H-Y, Xu S-H, Jiang H-X (2010) Acta Cryst E66:o1861

9. Duax WL, Norton DA (1975) Atlas of Steroid Structure, Vol. 1. Plenum, New York, pp 16-22

10. Hsu B, Schlemper EO (1980) Acta Cryst B36:3017

11. Allen FH (2002) Acta Cryst B58:380

12. Agilent Technologies (2010) CrysAlis PRO

13. Farrugia LJ (1999) J Appl Cryst 32:837

14. Altomare A, Cascarano G, Giacovazzo C, Guagliardi A (1993) J Appl Cryst 26:343

15. Sheldrick GM (2008) Acta Cryst A64:112

information may be obtained free of charge from: The Director, CCDC, 12 Union Road, Cambridge, CB2 1EZ, UK. Fax: +44(1223)336-033, e-mail:deposit@ccdc.cam. ac.uk, or www: www.ccdc.cam.ac.uk. 